rapid release of younger women. Mr. Hooper lays considerable stress on the patriotic appeal, sufficiently so to raise the question as to whether it is right to allow non-industrial industry to utilize part-time labour in this way unless it can be demonstrated that all munition and other essential industrial demands for labour have been fully met. Apart from this the paper lays down a number of principles which are clearly of value in launching any such scheme and which go far to determine success. The regular character of the job and that it is for a fixed time during the day or fixed days during the week, as well as the importance of regularity in time and attendance are impressed on all applicants, and few applicants failed to fit themselves into one or other of the schemes scheduled by Messrs. Lewis's, Ltd. Firm handling of this problem, Mr. Hooper said, has reduced bad time-keeping and absenteeism to a minimum. Much stress is also put on proper welfare arrangements and adequate training, and on the importance of utilizing all the usual means for getting the new employees over the early and most difficult stages of their employment. Accordingly, although a fairly large proportion of the first applicants were lost, fewer really unsuitable applicants are coming forward. Moreover, the firm has been surprised at the comparative ease with which parttime workers have fitted into their administration and at the quality of the part-time workers themselves, the average age of whom was about forty-five.

In addition to the stress on the importance of welfare and personnel work, for which a member of the Board has always been responsible, there is in each business a staff manager with high administrative authority and strictly commercial responsibility, with both a Welfare Department and a Staff Training Department. Mr. Hooper also stressed the extreme importance of explaining the scheme in advance to the management and full-time staff and of securing their co-operation and sympathy. As a result of this handling of the psychological difficulties and the putting out of clear instructions rather than appeals, in no section has there been any real difficulty in employing part-time workers. Two main methods were used. Where work requires verification and constant reference, a team of two or four parttimers work in association with one full-timer. In specialized office work wherever possible part-time workers take individual responsibility for their particular work, the size of self-balancing ledgers and salary books, for example, being reduced so that the workers can complete their work during the shortened hours. This usually works better than a team of two, one morning and one afternoon, being conducive to individual pride in one's work and avoiding the tendency for one half of the team blaming the other for mistakes. All the privileges of the regular staff are accorded to the part-time workers, who are expected to observe the same standard of discipline; the use of the term 'auxiliary' for the part-time staff has also promoted friendly relations and appealed to the patriotism of both.

\section{Drying Blood Plasma and Blood Serum}

The Trustees of the late Sir Henry S. Wellcome have generously placed a sum of up to $£ 20,000$ at the disposal of the Medical Research Council for the purposes of research into methods of drying blood plasma and blood serum to provide stable products for use in the transfusion of patients suffering from hæmorrhage, shock, or other conditions requiring such treatment. By agreement between the Trustees and the Council, this gift is to be applied to the purchase, erection and operation by the Council of a plant which will make it possible to test and develop these methods on a substantial scale. The need for the improvement of such methods is of particular importance at the present time, and the products will be made freely available for the treatment of sick and wounded at home, at sea and abroad. The Medical Research Council has expressed its appreciation of this timely and public-spirited action on the part of the Wellcome Trustees.

\section{Dr. Alès Hrdlička}

THE retirement of Dr. Alæs Hrdlička from the curatorship of the Division of Physical Anthropology in the National Museum, Washington, which he has held for almost forty years, is an event which no scientific journal can leave unnoted. Under him there has grown up in the National Museum one of the greatest-if not the greatest-collections of anthropological material in all the world; he is founder and leader of the enterprising school of physical anthropology which now flourishes in the United States. Born in Czechoslovakia in 1869, he was still a youth when his family emigrated to the United States; there he became a student of medicine and it was through the medical portal he entered upon the anthropological problems of the human body. On the anniversary of his seventieth birthday a list of his contributions to anthropology was compiled; they are now more than three hundred in number, covering every aspect of his subject, every one of them making a factual addition to a particular department of knowledge.

Dr. Hrdlička is beyond doubt the most travelled anthropologist of his time; there is no part of the world he has not visited in search of material and of knowledge. He made the circuit of the world several times to examine and report on the fossil remains of early man. His reports, issued from time to time in the publications of the Smithsonian Institution, are recognized throughout the world as the most reliable sources of fact relating to the discoveries of fossil man. His studies on the Old Americans (men and women of British ancestry), of the American Indians and of the Negro population of the United States have become classics. He has sought to trace the first peopling of the New World from a Mongolian homeland in north-east Asia and has explored Alaska for evidence of early migrations. In Alaska, too, he has dug up cemeteries attached to older Eskimo settlements; he has added greatly to our knowledge of the Eskimo, both ancient and modern. Dr. Hrdlička made warm friends wherever he went, particularly in England. $\mathrm{He}$ lectured in London in 1939 while on his way to the U.S.S.R. to examine the various finds of fossil man which have been made there in recent years. In 1926 his Czech colleagues issued a "Hrdlička" number of Anthropologio in honour of their distinguished countryman. At the close of the War of 1914-18 he founded the American Journal of Physical Anthropology, now the leading publication of its kind.

\section{New Zealand Earthquakes}

A STRONG earthquake shook a considerable area in New Zealand at about 11.18 p.m. (local time) on June 24. The places most affected were Masterton, 
Eketahuna, Greytown and Carterton. Property in Wellington and Palmerston North was damaged. At the southern end of the North Island, therefore, extensive minor damage was done over a wide area, windows being broken, chimneys dislodged and so forth, though no casualties have been reported. Buildings erected since 1933 under the earthquake by-laws (similar to those in force in many parts of California), have suffered only superficial damage. The main shock was preceded by a precursor shock at 8.15 p.m. (local time). The principal shock is said to have been the most severe since February 1931, when more than two hundred people were killed in the Hawke's Bay region as the result of a very severe earthquake. New Zealand is a seismic region, and hundreds of minor shocks occur every year. The study of these, and the multitude of seismological problems which arise, is actively pursued at Wellington, and we await further news of the present shock from the Dominion Observatory.

During March 1942, nine distant earthquakes were registered by the seismographs at Wellington, Auckland, Christchurch and Arapuni in New Zealand, according to the seismological bulletin just received from the Dominion Observatory, Wellington. The greatest appears to have been on March 5, when the ground movement at Wellington was $3 \mathrm{~mm}$. downwards, and the shock is estimated to have had its epicentre some $82^{\circ}$ from Wellington with a focus rather deeper than normal. The shock was recorded at Wellington at $20 \mathrm{~h} .00 \mathrm{~m}$. 51s. U.T. Microseisms interfered with the registration and the interpretation of the records throughout the month.

Additionally, 21 local earthquakes were recorded. The greatest was of intensity 6 on the Rossi-Forel scale (ringing of bells, stopping of clocks, visible disturbance of trees and shrubs, etc.), which occurred on March 25 at $15 \mathrm{~h} .49 \cdot 6 \mathrm{~m}$. U.T. and was felt at Milford Sound and Queenstown. Six subsequent shocks were felt in the same area though they were of lesser intensity. Other areas affected by earthquake activity were Opotiki (March 2), Motu (March 3 and 5), Pipiriki and Whangamomona (March 5, 6, 10, 12, 16 and 18), Napier and Hastings (March 20), and Te Whaiti and Taupo (March 22). Focal depths of these local earthquakes have been estimated to range from normal (about $16 \mathrm{~km}$.) to $100 \mathrm{~km}$. The bulletin is stated to be provisional, but it contains much useful data.

\section{Colour of Machines and Workshop Efficiency}

UNDER the title "Color for Efficiency", Matt Denning and Arthur A. Brainerd have described experiments made in an American machine shop by re-painting the machines in pale colours (Product Engineering, Jan., 1942). Machines are usually painted black or battleship grey, and their surfaces thus have a low reflexion factor. There is often too little brightness of colour contrast between the work and parts of machines forming its background. If these parts are finished with light-coloured paint, contrast is improved, and the work made easier to see. Moreover, the illumination of the work itself may be improved by light reflected from machine surfaces. The whole machine may be painted a uniform colour, or a different, but also pale, colour can be used for parts not in close proximity to the work. The general brightness of a machine shop is enhanced by this treatment. Where high machines, such as heavy presses, are used, a high reflectivity of their superstructure means that more light is reflected to adjacent machines, and troublesume shadows may be avoided. The colours tested were ranked on the results of a work-time study and on opinions of machine operators and measurements of reflexion factors. Light buff proved best, then aluminium and light grey. Yellow was found to be tiring. In Great Britain, the advantages of painting machines a light colour were recognized by the Departmental Committee on Factory Lighting, which recommended this practice in its fifth report, published in 1940 ; recent trials here have proved very satisfactory.

\section{Hormone Sprays for Fruit}

THE recent rapid developments in the investigation of growth-promoting substances have been closely followed by widespread attempts to apply the socalled plant hormones in horticultural practice. The use of synthetic growth substances to facilitate the rooting of cuttings became a craze almost overnight, and there is no doubt that remarkable results were achieved in many cases. There are still, however, species which resist all attempts to make them produce roots readily enough to make this method of propagation practicable on a commercial scale.

Other uses for growth substances have now become the centre of interest, and these form the subject of a review in the American Fruit Grower of June 1941. Perhaps the most successful application has been the use of naphthalene acetic acid and naphthalene acetamide to control the pre-harvest drop of apples. Spraying with dilute solutions of these substances, by delaying the formation of the abscission layer, enables fruits to be kept on the tree until a desirable degree of colour and maturity is reached. Fruit dropping from pears, plums, apricots, oranges and cherries has also been reduced, and, in the case of the latter, the sprayed fruits showed a lower acid and higher sugar content than the controls. Satisfactory results with some English varieties of apple have been obtained by similar methods at the East Malling and Long Ashton Research Stations. The method appears to be of particular value in com. bating the effects of strong winds. Also of interest is the checking of bud development by hormone sprays. By this means the risk of frost injury to fruit blossoms in spring may be reduced. Indole butyric acid, applied unilaterally to growing shoots of young apple trees, causes more rapid growth on the treated side. By this means the development of narrowangled and therefore structurally weak crotches can be avoided.

\section{Porcelain Insulators}

WrItring in the Electrical Review of June 12, 1942, on the design of electrical insulators in relation to manufacturing processes, Dr. E. Rosenthal points out that methods of shaping ceramic materials are based on the plastic quality of the china clay and ball clay in the case of porcelain, and of clay, talcum or bentonite in the case of certain ceramics. The plasticity of ceramic materials is caused by the adsorption of water at the surface of the kaolinite crystals forming the china and ball clays, this water surrounding the clay molecule. The forces which attract the water to the molecules and crystals are electrical in origin and impart to the clay molecules their colloidal and plastic nature. The hygroscopic water and the "water of formation" form the colloidal gels which give to the clay particles their plastic 